\title{
PENGEMBANGAN ENTERPRISE RESOURCE PLANNING (PLANT MAINTENANCE) BERBASIS FRAMEWORK ACUMATICA (STUDI KASUS: MODUL MAINTENANCE)
}

\author{
Heri Purwanto ${ }^{1)}$, Santa Yusuf Nasution ${ }^{2)}$, Sherly Deastuti ${ }^{3)}$ \\ Program Studi Teknik Informatika ${ }^{1), 2), 3)}$ \\ STMIK LPKIA ${ }^{1,2), 3)}$ \\ heripurwanto@1pkia.ac.id ${ }^{1)}$, santayusuf@gmail.com ${ }^{2)}$, sherlydeastuti@lpkia.ac.id ${ }^{3)}$
}

\begin{abstract}
ABSTRAK
Bersamaan dengan begitu pentingnya peralatan/mesin bagi keberlangsungan suatu perusahaan terutama perusahaan industri dalam membuat produk yang sesuai dengan harapan/tujuan perusahaan, maka dibutuhkan pemeliharaan secara khusus agar mesin yang digunakan dapat berjalan dengan performa yang baik sehingga meminimalkan terjadinya kerusakan mesin yang dapat menghambat fungsi bisnis perusahaan. Pada penelitian ini menggunakan modul untuk pemeliharaan mesin yaitu Plant Maintenace yang merupakan salah satu modul yang terdapat dalam bagian Enterprise Resource Planning (ERP). Modul ini merupakan gabungan dari semua tugastugas teknis, administrasi dan manajemen yang dilakukan selama siklus hidup dari suatu technical object untuk tetap beroperasi atau untuk dapat mengembalikan ke kondisi semula sehingga peralatan/mesin dapat bekerja sebagaimana yang diharapkan. Pada dasarnya Plant Maintenance terdiri dari 4 tugas, yaitu Inspection, maintenance, repair dan improvement. Setelah sebelumnya dilakukan penelitian yang menfokuskan pada modul inspection, pada penelitian ini akan berlanjut pada modul maintenance. Penelitian ini menggunakan framework Acumatica yaitu framework yang dibangun diatas Microsoft .NET dan Microsoft Visual Studio IDE dan dibuat dengan menggunakan bahasa pemrograman C\#. Acumatica merupakan framework yang dapat digunakan untuk membuat program berbasis ERP.
\end{abstract}

Kata Kunci: Enterprise Resource Planning, Plant Maintenance, Maintenance, Acumatica.

\section{PENDAHULUAN}

Proses bisnis suatu perusahaan dapat dibantu dengan adanya teknologi, sama halnya dengan perusahaan industri. Perusahaan ini membutuhkan perhatian khusus pada bagian produksinya. Peralatan/mesin yang digunakan untuk memproduksi setiap produk harus memiliki performa yang baik.

Salah satu sistem informasi manajemen yang dapat membantu permasalahan adalah Enterprise Resource Planning (ERP) yaitu sistem informasi yang mengintegrasikan dan mengotomatisasi berbagai praktek bisnis yang berelasi dengan aspek produksi atau operasi perusahaan. [1]

Pada ERP terdapat modul yang digunakan dalam proses pemeliharaan peralatan $/$ mesin yaitu Plant Maintenance. Modul ini pada dasarnya terdiri dari 4 tugas, yaitu: Inspection, maintenance, repair dan improvement. [3]
Saat ini masih banyak perusahaan yang tidak memiliki perencanaan pemeliharaan mesin yang baik, sehingga sering timbulnya masalah akibat dari kerusakan mesin yang tidak secara cepat ditangani.

Penelitian ini hanya berfokus pada modul maintenance dan hanya mengembangkan proses Corrective Maintenance, yaitu proses yang menggambarkan adanya kebutuhan pemeliharaan suatu mesin yang disebabkan oleh menurunnya performa mesin tersebut.

Penelitian ini diharapkan dapat membantu mengurangi permasalahan yang sering terjadi, akibat dari:

1. Proses Pemeliharaan yang sering terlambat yang menggangu kegiatan produksi.

2. Tidak adanya pengecekan fisik mesin secara rutin.

3. Kuantitas dan kualitas produk menurun. 
4. Meningkatnya kerugian biaya perawatan mesin terhadap mesin yang rusak.

5. Terjadi kecelakaan kerja akibat dari kerusakan mesin.

Batasan permasalahan dari sistem yang dikembangkan adalah:

1. Sistem yang dikembangkan berfokus pada Corrective Maintenance.

2. Modul Plant Maintenance yang digunakan hanya berfokus pada area Maintenance.

3. Aplikasi dibuat dengan menggunakan Acumatica Framework dan database SqlServer2014.

Dari identifikasi permasalahan diatas, maka tujuan yang ingin diraih adalah:

1. Proses pemeliharaan dapat dilakukan secara cepat dan tepat.

2. Mesin dapat digunakan dalam jangka waktu yang lebih lama.

3. Meningkatkan kuantitas dan kualitas produk.

4. Memperkecil biaya perawatan.

5. Meningkatkan kemanana operasi.

\section{DASAR TEORI}

\subsection{Enterprise Resource Planning (ERP)}

Menurut (Alexis Leon, 2014) mendefinisikan Enterprise Resource Planning sebagai berikut ini.

Enterprise Resource Planning is a techniques and concepts for integrated management of businesses or management of business as a whole with the objective of efficient and effective use of management resources and to improve the efficiency of enterprise management.

Berdasarkan pengertian diatas, maka dapat disimpulkan bahwa ERP adalah teknik dan konsep pengelolaan terpadu bisnis / manajemen bisnis secara keseluruhan dengan tujuan penggunaan sumber daya manajemen secara efisien dan efektif dan untuk meningkatkan efisiensi pengelolaan perusahaan.

\section{Keuntungan Penggunaan ERP}

Adapun keuntungan ERP secara langsung:

1. Integrasi Bisnis
2. Fleksibel

3. Analisis yang lebih baik dan kapabilitas perencanaan.

4. Penggunaan teknologi terbaru.

\subsection{Plant Maintenance}

Menurut (Karl Liebstückel, 2011) mendefinisikan Plant Maintenance sebagai berikut ini.

Plant maintenance is a combination of all technical, administrative, and management tasks carried out during the lifecycle of a technical object to keep it operational or to return it to this condition so it can work as intended. it essentially comprises the following four tasks: inspection, maintenance, repair, and improvement.

Berdasarkan pengertian diatas, maka dapat disimpulkan bahwa Plant Maintenance adalah gabungan dari semua tugas teknis, administrasi, dan manajemen yang dilakukan selama siklus hidup dari suatu technical object untuk tetap beroperasi / untuk mengembalikannya ke kondisi semula sehingga dapat bekerja sebagaimana yang diharapkan. Pada dasarnya terdiri dari 4 tugas, yaitu: Inspection, maintenance, repair, dan improvement.

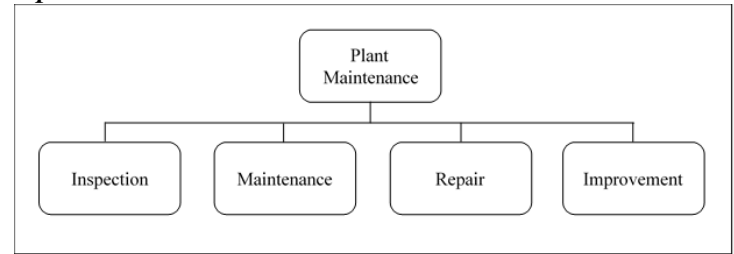

Gambar 1. New Maintenance Terminology (Sumber: Karl Liebstückel, 2011)

\subsection{Maintenance}

Pada penelitian ini Terminologi pemeliharaan baru yang digunakan hanya modul maintenance.

Maintenance sebagai semua tugas untuk menunda pengurangan dari penggunaan alternatif. Secara khusus, maintenance terdiri dari beberapa tugas, diantaranya:

1. Visually inspect (inspeksi secara visual)

2. Adjust (menyesuaikan)

3. Replace (menggantikan)

4. Supplement (melengkapi)

5. Lubricate (memberikan pelumas)

6. Preserve (mempertahankan)

7. Clean (membersihkan) 


\section{Function test (pemeriksaan fungsi)}

\subsection{Acumatica Framework}

Acumatica Framework adalah sebuah platform pengembangan aplikasi web modern yang dirancang untuk mengembangkan aplikasi bisnis. Acumatica Framework dibangun diatas Microsoft.NET dan Microsoft visual studio IDE technologies, acumatica framework dirancang dan dibuat dengan menggunakan bahasa pemograman C\#. [8]

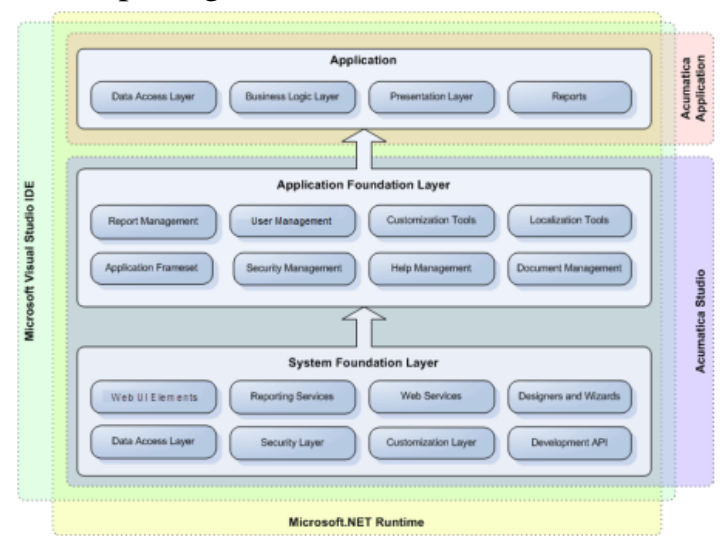

Gambar 2. Acumatica Framework Component

(Sumber: Acumatica, Inc., 2013)

\section{System Foundation Layer}

System foundation layer adalah pengatur untuk komponen inti dan primitif dengan fungsionalitas yang di perlukan untuk mengembangkan dan menjalankan aplikasi berbasis Acumatica Framework.

\section{Aplication layer foundation}

Aplication layer foundation mengatur application building blocks dan mengimplementasian struktur database berada di atas komponen system foundation layer.

\section{Data Access Layer}

Data Access Layer diimplementasikan sebagai pengatur data access classes yang membungkus data dari tabel database atau data yang diterima dari sumber eksternal lainnya.

\section{Business Logic Layer}

Business Logic adalah pengimplementasian business logic controller.

\section{Presentation Layer}

Presentation layer bertanggung jawab untuk menyediakan access ke business logic sebuah aplikasi melalui GUI. Terdiri dari pengaturan pendeklarasian web forms untuk business logic controller tertentu.

\section{ANALISIS DAN PERANCANGAN}

3.1. Aliran Proses

\subsubsection{Usecase Diagram}

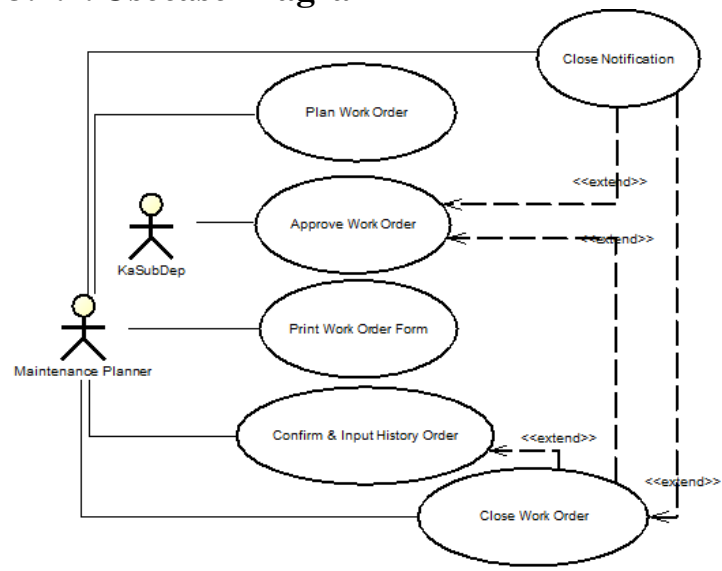

Gambar 3. Usecase Diagram Aplikasi Plant Maintenance (Modul Maintenance)

\subsubsection{Usecase Scenario}

Tabel 1. Usecase Scenario Plan Work Oder

Usecase Scenario Plan Work Order

\begin{tabular}{|l|l|}
\hline $\begin{array}{l}\text { Uraian } \\
\text { Singkat }\end{array}$ & Merencanakan Work Order \\
\hline Actor & Maintenance Planner \\
\hline Trigger Event & \\
\hline PreCondition & $\begin{array}{l}\text { Maintenance Planner memilih } \\
\text { fungsi Plan Work Order }\end{array}$ \\
\hline PostCondition & $\begin{array}{l}\text { Sistem menyimpan data Work } \\
\text { Order ke database }\end{array}$ \\
\hline Priority & \\
\hline
\end{tabular}

SCENARIO

1. Maintenance Planner memilih fungsi Plan Work Order.

2. Sistem menampilkan form Work Order.

3. Maintenance Planner memilih nomor Work Order yang akan dilakukan perencanaan.

4. Sistem menampilkan data Work Order.

5. Maintenance Planner memasukkan dan menyimpan data Work Center, Activity Type dan Duration .

6. Maintenance Planner memasukkan dan menyimpan data alokasi aktivitas external.

7. Maintenance Planner memasukkan dan menyimpan data sparepart dan jumlah yang diperlukan.

8. Maintenance Planner melakukan penjadwalan work order yang direncanakan dan menyimpan data tersebut ke database.

9. Maintenance Planner mengeset status Work Order menjadi Order Planned, kemudian menyimpannya ke database. 
10. Sistem memvalidasi data yang dimasukkan Maintenance Planner.

11. Sistem menyimpan data Work Order ke database.

\section{ALTERNATIVES}

Jika terjadi kesalahan pada saat Maintenance Planner memasukan data, maka sistem akan menampilkan pesan error / tidak valid dan Maintenance Planner harus kembali memasukkan data yang valid.

EXTENSION

NOTE

Tabel 2. Usecase Scenario Approve Work Order

\begin{tabular}{|l|l}
\hline \multicolumn{2}{|c}{ Usecase Scenario Approve Work Order } \\
\hline
\end{tabular}

\begin{tabular}{|l|l|}
\hline Uraian & Menyetujui Work Order
\end{tabular}

\begin{tabular}{l|l} 
Singkat & \\
\hline Actor & Kentudi Work Order
\end{tabular}

\begin{tabular}{|l|l|}
\hline Actor & KaSubDep \\
\hline Trigger Event & \\
\hline PreCondition &
\end{tabular}

PreCondition $\quad$ KaSubDep memilih fungsi Approve Work Order

PostCondition Sistem menyimpan data Work Order ke database

\section{Priority}

SCENARIO

1. KaSubDep memilih fungsi Approve Work Order.

2. Sistem menampilkan form Work Order.

3. KaSubDep memilih data Work Order yang akan dilakukan persetujuan.

4. Sistem menampilkan data Work Order berdasarkan yang dipilih KasubDep.

5. KaSubDep memilih User Status "WAPR" (Approve to execute) / "WRJT" (Reject) / "WPSP" (Postpone).

6. KaSubDep menyimpan data Work Order.

7. Sistem memvalidasi data yang dimasukkan KaSubDep.

8. Sistem menyimpan data Work Order ke database.

\section{ALTERNATIVES}

Jika terjadi kesalahan pada saat KaSubDep melakukan proses Approve Work Order, maka sistem akan menampilkan pesan error / tidak valid dan KaSubDep harus kembali memasukkan data yang valid.

EXTENSION

NOTE

Tabel 3. Usecase Scenario Print Work Order Form

\begin{tabular}{|l|l|}
\hline \multicolumn{2}{|c|}{ Usecase Scenario Print Work Order Form } \\
\hline $\begin{array}{l}\text { Uraian } \\
\text { Singkat }\end{array}$ & $\begin{array}{l}\text { Mencetak form Work Order } \\
\text { untuk Teknisi }\end{array}$ \\
\hline Actor & Maintenance Planner \\
\hline Trigger Event & \\
\hline PreCondition & Maintenance Planner memilih \\
\hline
\end{tabular}

\begin{tabular}{|l|l|}
\hline \multicolumn{1}{|c|}{} & fungsi Print Work Order Form \\
\hline PostCondition & $\begin{array}{l}\text { Printer mencetak form Work } \\
\text { Order }\end{array}$ \\
\hline Priority & \\
\hline SCENARIO & \\
1. Maintenance Planner memilih fungsi Print \\
Work Order Form. \\
2. Sistem menampilkan data Work Order. \\
3. Maintenance Planner memilih data Work Order \\
yang akan dicetak. \\
4. Maintenance Planner memilih aksi cetak. \\
5. Sistem memvalidasi proses yang dilakukan \\
Maintenance Planner. \\
6. Sistem mengeset System Status menjadi "PRT" \\
(Printed). \\
7. Sistem mengeset User Status menjadi "WEXE" \\
(Order being executed). \\
8. Printer mencetak form Work Order. \\
\hline ALTERNATIVES \\
Jika terjadi kesalahan pada saat Maintenance \\
Planner melakukan proses Print Form Work \\
Order, maka sistem akan menampilkan pesan \\
error / tidak valid dan Maintenance Planner \\
harus kembali melakukan proses yang valid. \\
\hline EXTENSION \\
\hline NOTE
\end{tabular}

Tabel 4. Usecase Scenario Confirm \& Input History Order

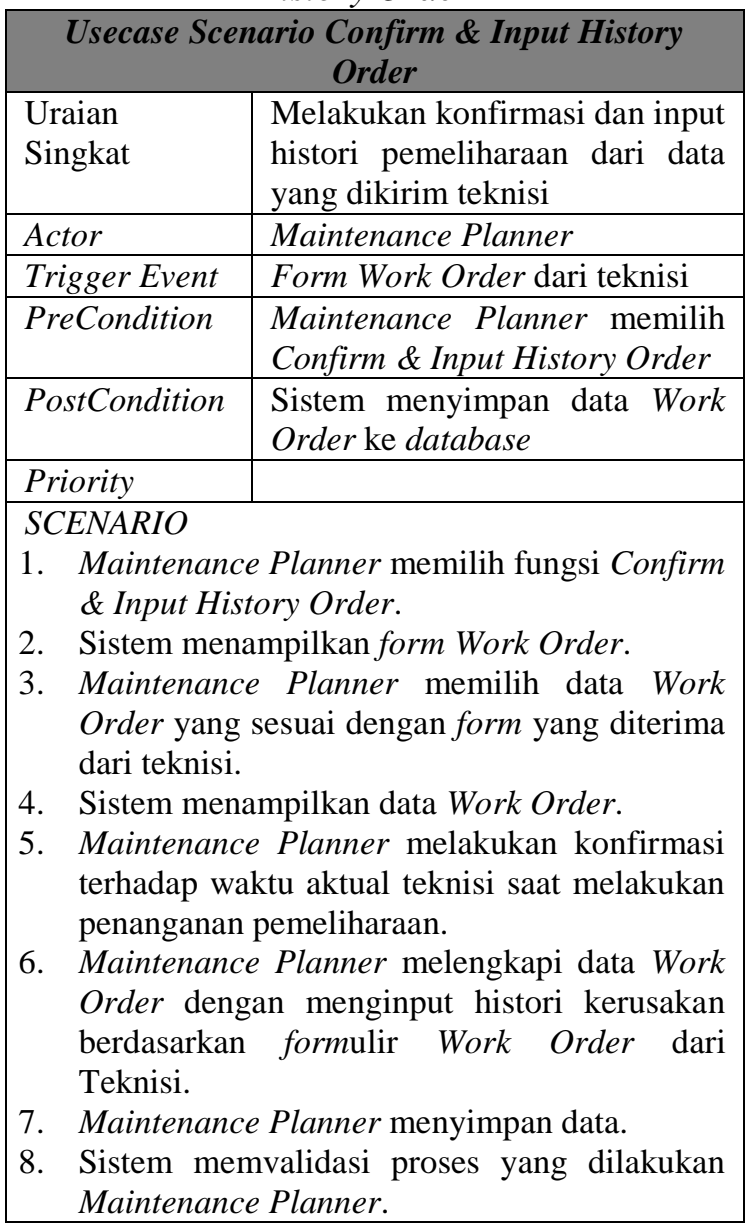


9. Sistem mengeset System Status menjadi "TECO" (Technically Completed).

10. Sistem menyimpan data Work Order ke database.

\section{ALTERNATIVES}

Jika terjadi kesalahan pada saat Maintenance Planner melakukan proses Confirm \& Input History Order, maka sistem akan menampilkan pesan error / tidak valid dan Maintenance Planner harus kembali memasukkan data yang valid.

\section{EXTENSION}

NOTE

Tabel 5. Usecase Scenario Close Work Order Usecase Scenario Close Work Order

\begin{tabular}{|l|l}
\hline Uraian & Menutup Work Order
\end{tabular}

\begin{tabular}{l|l} 
Singkat & \\
\hline Actor & Maintenance Planner
\end{tabular}

Trigger Event $\quad$ Approve Work Order, Confirm \& Input History Order

PreCondition $\quad$ Maintenance Planner memilih fungsi Close Work Order

PostCondition $\quad$ Sistem menyimpan data Work Order ke database

Priority

SCENARIO

1. Maintenance Planner memilih fungsi Close Work Order.

2. Sistem menampilkan form Work Order.

3. Maintenance Planner memilih data Work Order yang akan diselesaikan.

4. Sistem menampilkan data Work Order.

5. Maintenance Planner memilih User Status "WCMP" (Compeleted) Work Order.

6. Maintenance Planner menyimpan data Work Order.

7. Sistem memvalidasi proses yang dilakukan Maintenance Planner.

8. Sistem mengeset system status Notification dengan nomor Work Order yang sama menjadi "NOCO ORAS" (Notification completed and Order assigned).

9. Sistem menyimpan data Work Order ke database.

\section{ALTERNATIVES}

Jika terjadi kesalahan pada saat Maintenance Planner melakukan proses Complete Work Order, maka sistem akan menampilkan pesan error / tidak valid dan Maintenance Planner harus kembali memasukkan data yang valid. EXTENSION

NOTE

Tabel 6. Usecase Scenario Close Notification

\begin{tabular}{|l|l|}
\hline \multicolumn{2}{|c|}{ Usecase Scenario Close Notification } \\
\hline $\begin{array}{l}\text { Uraian } \\
\text { Singkat }\end{array}$ & Menutup Notifikasi \\
\hline Actor & Maintenance Planner \\
\hline Trigger Event & \\
\hline
\end{tabular}

\begin{tabular}{|l|l|}
\hline PreCondition & $\begin{array}{l}\text { Maintenance Planner memilih } \\
\text { fungsi Close Notification }\end{array}$ \\
\hline PostCondition & $\begin{array}{l}\text { Sistem menyimpan data } \\
\text { Notification ke database. }\end{array}$ \\
\hline Priority & \\
\hline SCENARIO \\
1. Maintenance Planner memilih fungsi Close \\
Notification. \\
2. Sistem menampilkan form Notification. \\
3. Maintenance Planner memilih data \\
Notification yang akan ditutup. \\
4. Sistem menampilkan data Notification yang \\
dipilih. \\
5. Maintenance Planner memilih User Status \\
"Close" dan menyimpan ke database. \\
6. Sistem mengeset System Status menjadi \\
"NOCO" (Notification Completed). \\
7. Sistem memvalidasi data yang dimasukkan \\
Maintenance Planner. \\
8. Sistem menyimpan data Notification ke \\
database. \\
\hline ALTERNATIVES \\
Jika terjadi kesalahan pada saat Maintenance \\
Planner memasukan data, maka sistem akan \\
menampilkan pesan error / tidak valid dan \\
Maintenance Planner harus kembali \\
memasukkan data yang valid. \\
\hline EXTENSION \\
\hline NOTE \\
\hline
\end{tabular}

\subsection{Aliran Kerja (Activity Diagram)} III.2.1. Plan Work Order

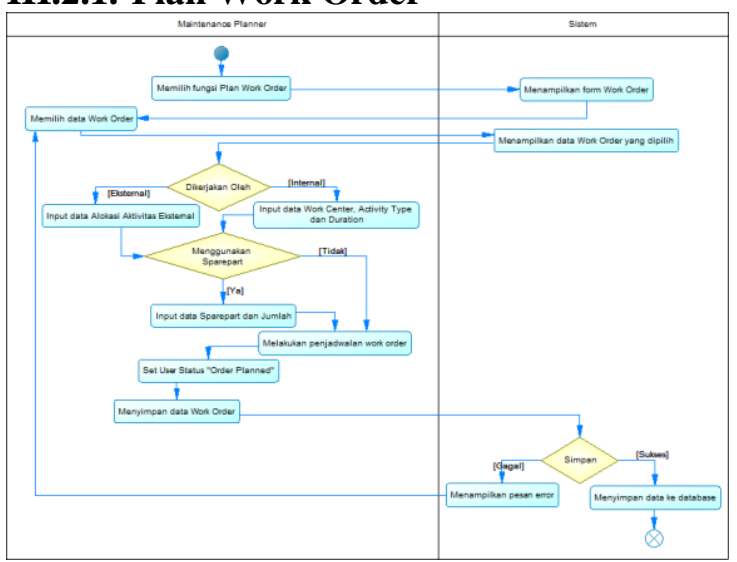

Gambar 4. Activity Diagram Plan Work Order

\section{Uraian Workflow:}

1. Dalam gambar 4 dijelaskan bagaimana melakukan perencanaan work order.

2. Langkah pertama, Maintenance Planner memilih fungsi Plan Work Order.

3. Sistem akan menampilkan form Work Order.

4. Maintenance Planner memilih data Work Order yang akan dilakukan perencanaan. 
5. Sistem menampilkan data Work Order yang dipilih.

6. Maintenance Planner menginput data Alokasi Aktivitas Eksternal apabila pemeliharaan dilakukan oleh pihak eksternal atau menginput data Work Center, Activity Type dan Duration apabila pemeliharaan dilakukan oleh pihak internal.

7. Maintenance Planner menginput data sparepart dan jumlahnya, serta melakukan penjadwalan work order apabila pemeliharaan menggunakan sparepart atau melakukan penjadwalan work order saja apabila pemeliharaan tidak menggunakan sparepart.

8. Maintenance Planner mengeset user status menjadi "Order Planned" dan menyimpan data work order.

9. Sistem akan mengecek data yang diinput, apabila data yang diinput valid dan dinyatakan sukses maka sistem akan menyimpan data tersebut ke database. Jika gagal maka sistem akan menampilkan pesan error dan Maintenance Planner harus mengulang proses input data yang valid.

\section{III.2.2. Approve Work Order}

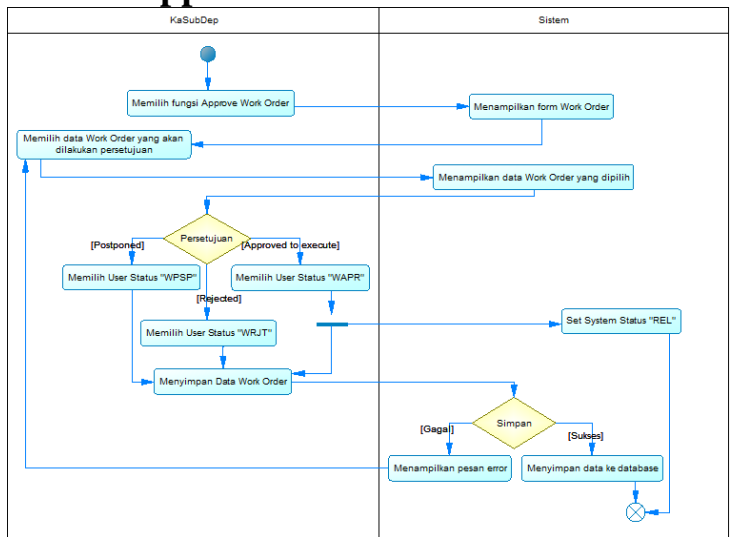

Gambar 5. Activity Diagram Approve Work Order

\section{Uraian Workflow:}

1. Dalam gambar 5 dijelaskan bagaimana melakukan persetujuan work order.

2. Langkah pertama, KaSubDep memilih fungsi Approve Work Order.

3. Sistem menampilkan form Work Order.

4. KaSubDep memilih data Work Order yang akan dilakukan persetujuan.

5. Sistem menampilkan data Work Order yang dipilih.
6. KaSubDep memilih user status "WPSP" apabila menunda (postponed) persetujuan, memilih user status "WRJT" apabila menolak (rejected) persetujuan, atau memilih user status "WAPR" apabila menyetujui (approved to execute) persetujuan yang secara otomatis sistem mengeset system status menjadi "REL".

7. KaSubDep menyimpan data work order.

8. Sistem akan mengecek data yang diinput, apabila data yang diinput valid dan dinyatakan sukses maka sistem akan menyimpan data tersebut ke database. Jika gagal maka sistem akan menampilkan pesan error dan KaSubDep harus mengulang proses input data yang valid.

III.2.3. Print Work Order

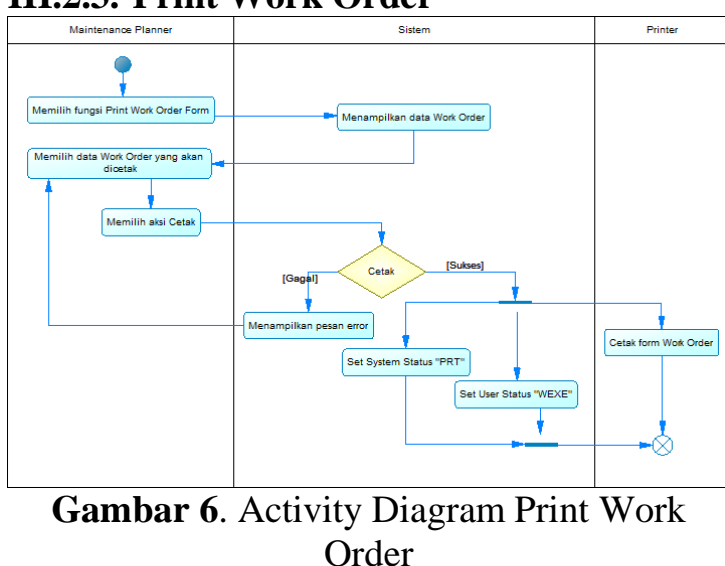

Uraian Workflow:

1. Dalam gambar 6 dijelaskan bagaimana melakukan proses cetak work order.

2. Langkah pertama, Maintenance Planner memilih fungsi Print Work Order.

3. Sistem akan menampilkan data Work Order.

4. Maintenance Planner memilih data Work Order yang akan dicetak dan memilih aksi cetak.

5. Sistem akan mengecek data yang diinput, apabila data yang diinput valid.

\section{III.2.4. Confirm \& Input History Order}




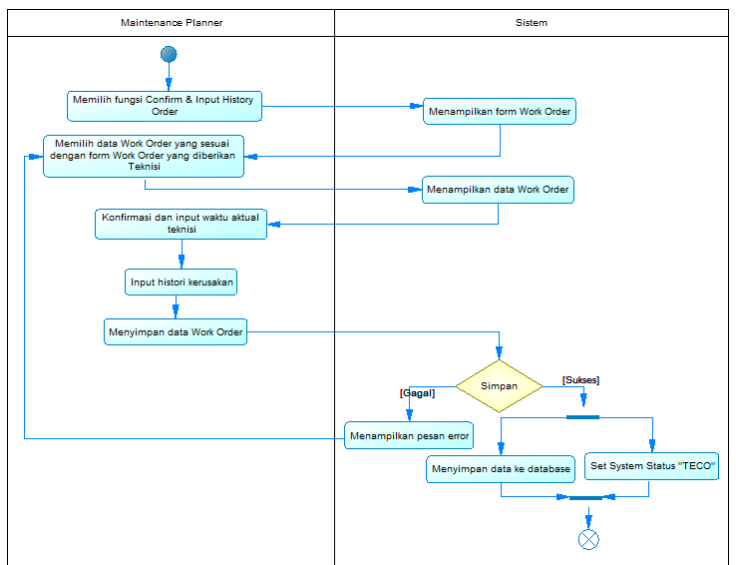

Gambar 7. Activity Diagram Confirm \& Input History Order

\section{Uraian Workflow:}

1. Dalam gambar 7 dijelaskan bagaimana melakukan konfirmasi dan input history order.

2. Langkah pertama, Maintenance Planner memilih fungsi Confirm \& Input History Order.

3. Sistem akan menampilkan form Work Order.

4. Maintenance Planner memilih data Work Order yang sesuai dengan formulir work order yang diberikan oleh teknisi.

5. Sistem menampilkan data Work Order yang dipilih.

6. Maintenance Planner melakukan konfirmasi dan input waktu aktual teknisi, input history kerusakan dan menyimpan data yang diinput tersebut.

7. Sistem akan mengecek data yang diinput, apabila data yang diinput valid dan dinyatakan sukses maka sistem akan menyimpan data tersebut ke database. Jika gagal maka sistem akan menampilkan pesan error dan Maintenance Planner harus mengulang proses input data yang valid.

\section{III.2.5. Close Work Order}




\section{Uraian Workflow:}

1. Dalam gambar 9 dijelaskan bagaimana cara melakukan penutupan notification.

2. Pertama, Maintenance Planner memilih fungsi Close Notification.

3. Sistem akan menampilkan form Notification.

4. Maintenance Planner memilih data Notification yang akan ditutup.

5. Sistem menampilkan data Notification yang dipilih.
6. Maintenance Planner memilih user status "Close" yang secara otomatis sistem akan mengeset system status menjadi "NOCO".

7. Maintenance Planner menyimpan data Notification.

8. Sistem akan mengecek data yang diinput, apabila data yang diinput valid dan dinyatakan sukses maka sistem akan menyimpan data tersebut ke database. Jika gagal maka sistem akan menampilkan pesan error dan Maintenance Planner harus mengulang proses input data yang valid.

\subsection{Pemodelan Data (Class Diagram)}

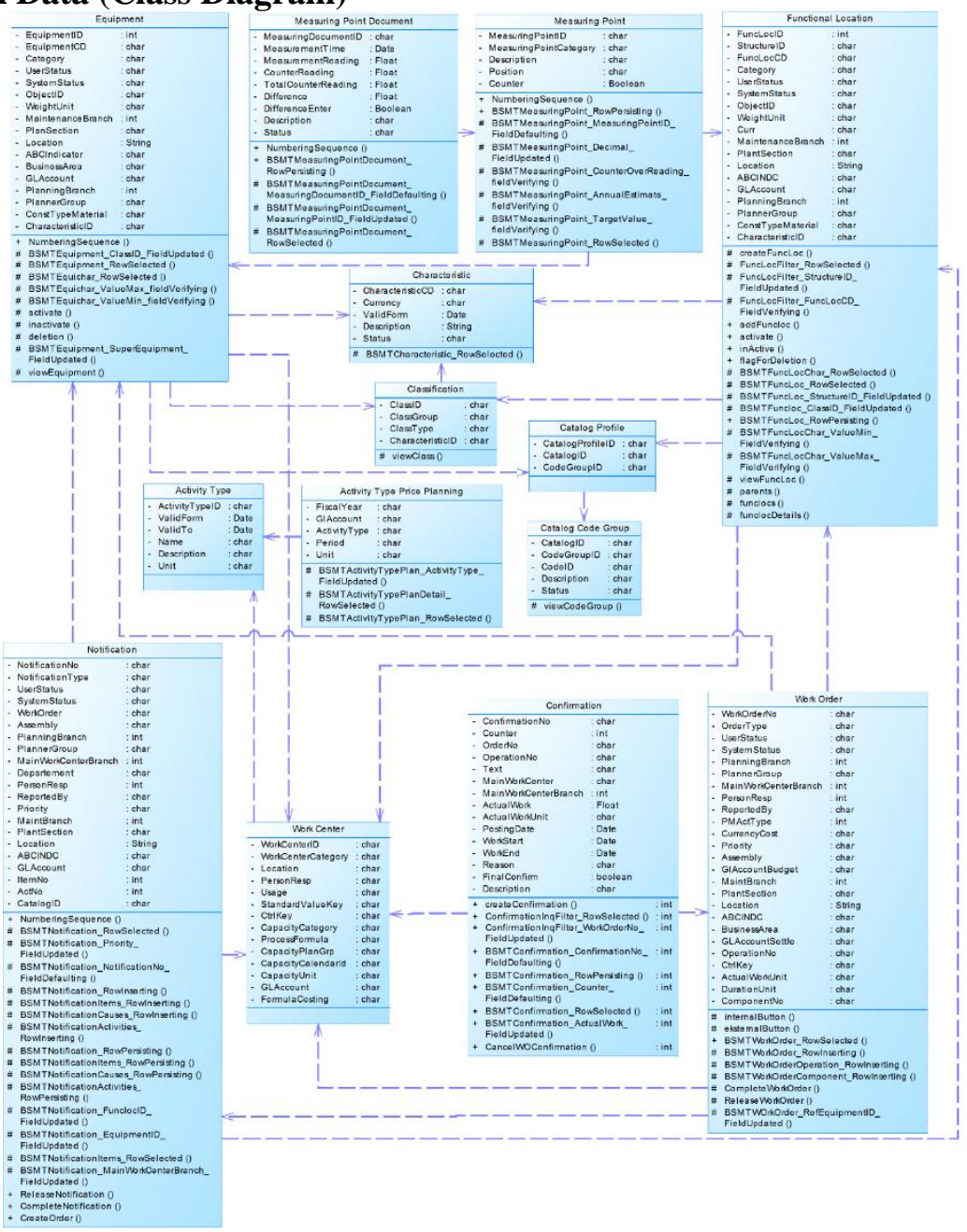

Gambar 10. Class Diagram Plant Maintenance

\section{IMPLEMENTASI}

IV.1. Implementasi Antarmuka

Work Order 


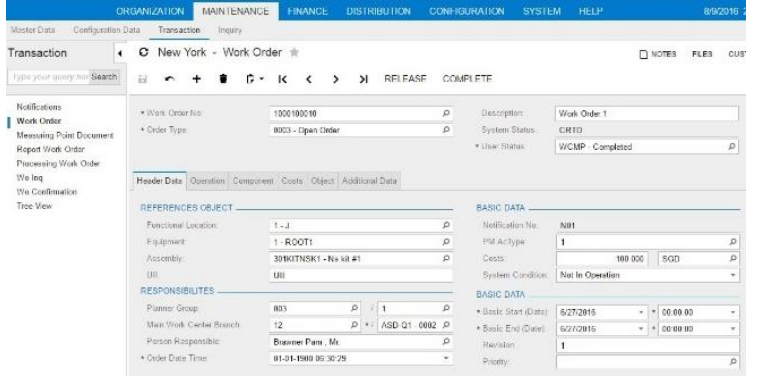

Gambar 11. Dialog Screen Work Order

Penjelasan Gambar 11 Dialog Screen Work Order

1. Halaman ini akan muncul saat pengguna memilih Work Order pada menu Maintenance $\rightarrow$ Transaction $\rightarrow$ Manage.

2. Pilih field Work Order No yang sudah tersedia berdasarkan hasil generate dari Notification.

3. Input data pada field yang harus diisi.

4. Pada saat akan memilih User Status, pilih telebih dahulu Order Type karena value dari User Status yang muncul berdasarkan dari konfigurasi Order Type.

5. Jika memilih data Equipment terlebih dulu, maka data Functional Location otomatis muncul sesuai dengan Equipment yang di pilih. Tetapi jika memilih data Functional Location terlebih dulu, maka isi selector Equipment akan mengacu kepada data Functional Location yang dipilih.

6. Pada tab Operation akan muncul grid. Isi grid tersebut dengan cara klik tombol New Line. Field Operation No akan muncul secara otomatis dari sistem yang akan berurutan mulai dari no "0001".

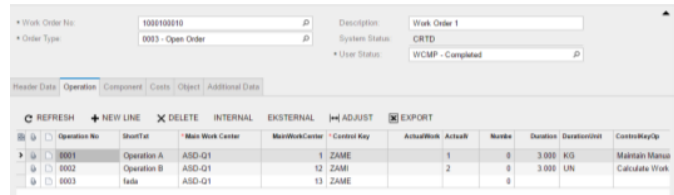

Terdapat 2 button INTERNAL dan EKSTERNAL, button tersebut berfungsi untuk memasukan data suatu operation apakan di kerjakan oleh pihak internal atau eksternal.

7. Pada tab Component berfungsi untuk mengisi komponen apa saja yang digunakan sebagai komponen dalam pengajuan Work Order. Cara menggunakan tab ini dengan cara mengklik tombol Add Row (+) untuk menambahkan komponen baru, field Component No akan secara otomatis muncul dengan nomor dimulai dengan no "0001" dan seterusnya.

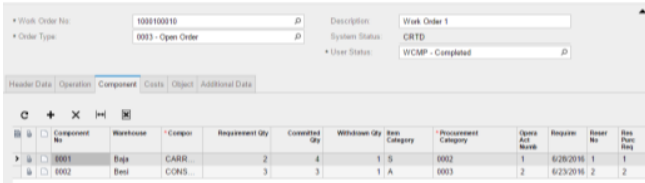

8. Tab Cost befungsi untuk menampilkan hasil dari estimated plan dan actual suatu Work Order. Field tersebut terisi secara otomatis.

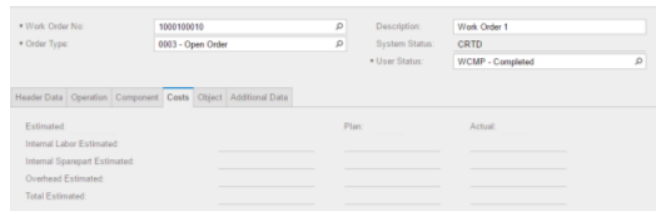

9. Tab Object digunakan untuk mengisi objek apa saja yang terlibat di dalam suatu Work Order.

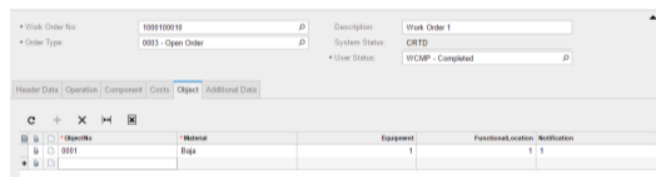

10. Tab Additional Data berfungsi untuk menginputkan additional data di dalam Work Order.

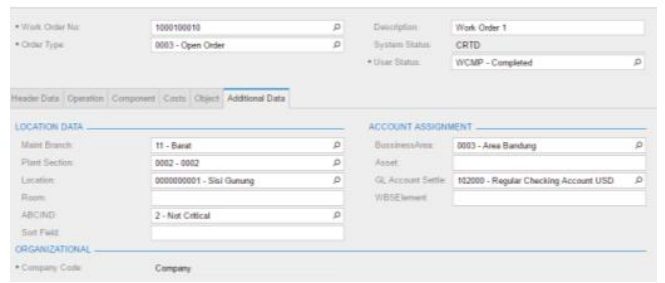

11. Untuk menyimpan data Work Order pilih

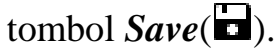

12. Untuk mengedit data Work Order, pilih selector Work Order No, cari dan pilih data yang akan di edit, maka data akan otomatis muncul pada screen ini. Setelah mengedit data, pilih tombol Save( agar data yang di edit tersimpan di database.

13. Untuk menghapus data Work Order, pilih selector Work Order No, cari dan pilih data yang akan di hapus, maka data akan otomatis muncul pada screen ini. Kemudian pilih tombol Delete( $)$.

\section{Confirmation}

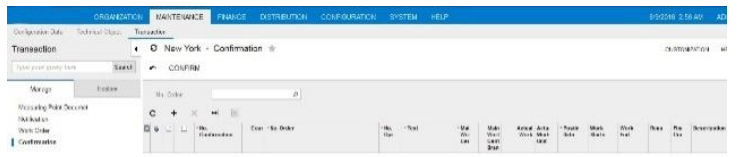


Gambar 12. Dialog Screen Confirmation (Operator Inquiry)

Penjelasan Gambar 12 Dialog Screen Confirmation (Operation Inquiry)

1. Halaman ini akan muncul saat pengguna memilih Confirmation Inquiry pada menu Maintenance $\rightarrow$ Transaction $\rightarrow$ Manage.

2. Pilih No order dari Selector No. Order: $\quad$, data yang tampil pada No. Order selector hanya order nomor yang memiliki operation dengan control key internal processing.

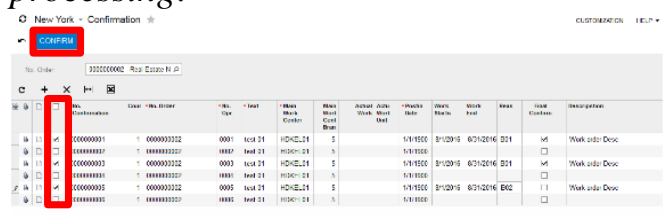

3. Data yang telah di konfirmasi tidak akan muncul kembali di dalam grid.

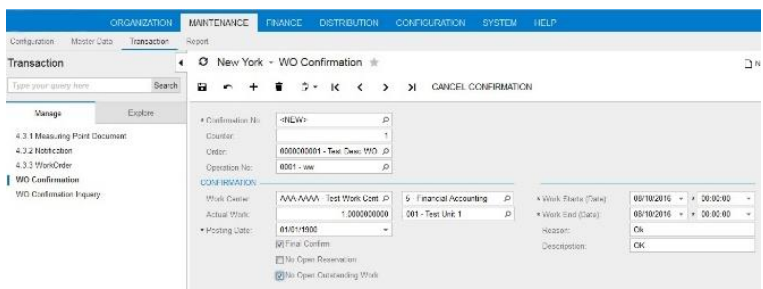

Gambar 13. Dialog Screen Confirmation (Work Order Confirmation)

Penjelasan Gambar 13 Dialog Screen Confirmation (Work Order Confirmation)

1. Halaman ini akan muncul saat pengguna memilih Confirmation pada menu Maintenance $\rightarrow$ Transaction $\rightarrow$ Manage.

2. Isi data Confirmation pada setiap field.

3. Untuk membatalkan konfirmasi, maka pilih tombol CANCEL CONFIRMATION. Dengan menekan tombol tersebut pada satu data confirmation, maka field Counter akan ditambah 1 dan field Actual Work Confirmation tersebut akan memiliki nilai minus (-).

4. Untuk menyimpan data Confirmation pilih tombol Save (⿳).

5. Untuk mengedit data Confirmation, pilih selector Confirmation No, cari dan pilih data yang akan di edit, maka data akan otomatis muncul pada screen ini. Setelah mengedit data, pilih tombol $\operatorname{Save}(\mathbf{Q})$ agar data yang di edit tersimpan di database.

\section{PENUTUP}

Setelah melakukan penelitian terhadap permasalahan yang ada, maka dapat disimpulkan bahwa penerapan hasil penelitian tim pengembang mengenai Plant Maintenance ini sangat akurat untuk digunakan di perusahaan, khususnya untuk perusahaan industri yang memiliki mesin-mesin yang harus dilakukan pemeliharaan dengan baik.

Dengan adanya perbaikan dalam proses pemeliharaan mesin dan dengan menggunakan teknologi berbasis cloud computing yang telah disesuaikan, maka akan sangat bermanfaat antara lain:

1. Proses pemeliharaan mesin menjadi semakin cepat dan teratur.

2. Mesin tidak mudah rusak dan dapat digunakan dalam jangka waktu yang lebih lama karena adanya pemeliharaan yang terencana.

3. Meningkatnya kuantitas dan kualitas produk perusahaan.

4. Biaya perawatan mesin menjadi lebih kecil karena kemungkinan kerusakan mesin lebih kecil selama mesin tersebut terpelihara dengan baik.

5. Meningkatnya keamanan operasi dari kesalahan yang terjadi akibat dari kerusakan mesin.

Sehubungan dengan hasil penelitian yang telah dilakukan oleh tim pengembang, maka saransaran yang dapat disampaikan untuk pengembangan lebih lanjut terhadap sistem Plant Maintenance ini adalah sebagai berikut:

Sistem dikembangkan lebih lanjut ke modul repair dan improvement.

\section{DAFTAR PUSTAKA}

[1] W. Siswoutomo, Panduan Karir di Dunia Teknologi Informasi, Jakarta: Elex Media Komputindo, 2005.

[2] A. Leon, Enterprise Resource Planning, New Delhi: McGraw Hill Education (India) Private Limited, 2014.

[3] K. Liebstïckel, Plant Maintenance with SAP, Boston: Galileo Press, 2011.

[4] A. Nugroho, Perancangan dan 
Implementasi Sistem Basis Data, vol. 1, Yogyakarta: Andi, 2011.

[5] M. Fowler, UML Distilled, Yogyakarta: Andi, 2005.

[6] A. Nugroho, Algoritma dan Struktur Data dengan C\#, Yogyakarta: Andi, 2009.

[7] P. K. Raum A. Mata-Toledo, Schaum's Outline Dasar-dasar Database Relational, Jakarta: Erlangga, 2007.

[8] Acumatica Inc., "Developer Guide Acumatica Framework 5.0," Development Guide, pp. 7-18, 2013.

[9] B. A. Masood-Al-Farooq, SQL Server 2014 Development Essentials, Birmingham: Packt Publishing, 2014.

[10] A. Nugroho, Rekayasa Perangkat Lunak
Berorientasi Objek dengan Metode USDP, vol. 1, Yogyakarta: Andi, 2010.

[11] Heri Purwanto, Santa YN, Sherly D Pengembangan ERP (Plant Maintenance) Berbasis Framework Accumatica (Studi Kasus Modul Inspection), STMIK LPKIA, Bandung, 2016

[12] R. S. Pressman, Rekayasa Perangkat Lunak, vol. 7, Yogyakarta: Andi, 2012.

[13] G. D. Gupta Mukul, Research Methodology, New Delhi: PHI Learning Pvt., 2011. 